\title{
MEMBANGUN ENTREPRENEURIAL INTENTIONS MAHASISWA \\ MELALUI PENDIDIKAN KEWIRAUSAHAAN
}

(Sebagai Upaya Menghadapi Masyarakat Ekonomi ASEAN “MEA”)

\author{
Heri Cahyono \\ Fakultas Agama Islam \\ Universitas Muhammadiyah Metro (UM Metro) \\ hericahyono808@gmail.com
}

\begin{abstract}
Abstrak
Menghadapi Masyarakat Ekonomi Asean (MEA) dibutuhkan sumber daya manusia yang memiliki komitmen dalam entrepreneur. sehingga pendidikan kewirausahaan menjadi salah satu upaya strategi dalam menjawab tantangan tersebut. Artikel ini bersifat deskriftif analitik yaitu menggunakan teori-teori para ahli untuk memberikan gambaran bahwa betapa pentingnya pendidikan kewirausahaan dalam membangun niat wirausaha mahasiswa. Sehingga dalam implementasinya pendidikan kewirausahaan dapat dilakukan melalui satu mata pelajaran atau melalui pengintegrasian dengan menanamkan berbagai kekuatan seperti head, heart, hand, health. Membangun niat dalam proses pendidikan kewirausahaan dapat dipengaruhi oleh berbagai faktor seperti faktor internal, eksternal dan kontekstual. Oleh karena itu, untuk mendorong timbulnya niat mahasiswa dalam berwirausaha setelah lulus sarjana perlu mendapat dukungan dari berbagai kalangan sebagaimana disebutkan, hingga lahirlah niat yang akan menjadi cerminan dari perilaku entrepreneur sesungguhnya.
\end{abstract}

Kata kunci. Entrepreneur intentions, pendidikan, kewirausahaan.

\begin{abstract}
In Facing ASEAN Economic Community (AEC) is required the human resources that have a good commitment to the entrepreneur. so that entrepreneurship education be one of strategy in an attempt to answer this challenge. The resechers used descriptive analyzis that use the experts' theory to show to the students in relating the importance of entrepreneurship education in building the entrepreneurial intentions. Thus, in the implementation of entrepreneurship education can be done through a single subject or by integrating with embed various powers such as the head, heart, hand, health. Building goodwill in the process of entrepreneurship education can be affected by various factors such as internal, external and contextual. Therefore, to encourage his students in entrepreneurship intentions after graduating scholars should receive support from various circles as mentioned, the intention was born to be a reflection of the behavior of the real entrepreneur.
\end{abstract}

Keyword. Entrepreneur intentions, Education, Entrepreneurship. 


\section{PEDAHULUAN}

Masyarakat Ekonomi Asean (Asean Economic Community) merupakan agenda besar yang diikuti oleh berbagai negara ASEAN sebagai usaha membangun ekonomi yang terintegrasi dengan menggunakan pasar bebas atau freetrade antar negara. Kerjasama ini dilakukan adalah tidak lain untuk meningkatkan daya saing agar mampu menyaingi seperti halnya Cina dan India. Kehadiran agenda besar tersebut memberikan kesempatan bagi masyarakat Indonesia dalam menunjukan produk-produk terbaiknya di kancah internasional karena memang program yang ditujukan di MEA tidak saja meliputi kebebasan aliran barang, tenaga kerja, aliran modal, namun juga untuk mengurangi kemiskinan serta kesenjangan sosial ekonomi. ${ }^{1}$ Namun selain menjadi sebuah kesempatan juga menjadi tantangan tersendiri bagai bangsa yang memiliki mental konsumtif.

Kesepakatan pelaksanaan Masyarakat Ekonomi Asean (Asean Economic Community) diikuti oleh 10 negara yang memiliki penduduk 600 juta jiwa dan $43 \%$ dari jumlah tersebut adalah berada di Indonesia, ini artinya pelaksanaan MEA sebenarnya akan menempatkan Indonesia sebagai pasar utama baik untuk arus barang maupun arus investasi. ${ }^{2}$ Dalam konteks arus barang yang perlu dicermati adalah sudahkah barang-barang lokal nasional mampu bersaing dengan produk-produk unggulan dari berbagai negara seperti Singapura, Thailand, Vietnam, Filiphina, Brunei darussalam, dan Malaysia, baik dari sisi harga maupun kualitasnya. Adapun dari konteks jasa sudahkan negeri ini mempersiapkan SDM yang kompeten.?

Kehadiran MEA tersebut tentu menjadi perhatian besar bagi semua kalangan baik pemerintah sebagai pengambil kebijakan, lembaga pendidikan sebagai pencetak SDM, masyarakat sebagai implementer dalam agenda tersebut. Menjadi sebuah harapan besar bagi kita semua mampu ikut bersaing dalam segala hal persaingan barang dan jasa sehingga tidak hanya menjadi penonton di negeri sendiri. Fenomena yang terjadi saat ini banyak sekali mahasiswa ketika lulus dari perguruan tinggi mereka hanya ingin menjadi seorang pegawai, ini terlihat dari banyaknya berkas-berkas lamaran kerja disetiap instansi perusahaan. dengan kata lain menjadi seorang karyawan masih menjadi dambaan banya mahasiswa setelah lulus dari perguruan tinggi. Ini menggambarkan betapa pola pikir untuk menjadi wirausaha di kalangan mahasiswa masih sangat kecil.

Hal ini menunjukan bahwasanya pemerintah dan dan masyarakat memiliki peran dalam memeprsiapkan tantangan tersebut maka dunia

1 Hadi Soesastro, Kebijakan Persaingan, Daya Saing, Liberalisasi, Globalisasi, Regionalisasi dan Semua Itu, Economics Working Paper Series CSIS, 2004.

2 Tukhas Shilul Imaroh, "Pendidikan Entrepreneurship Sebagai Strategi Peningkatan Daya Saing Bangsa dalam Menghadapi AEC." Prosiding Seminar Nasional "Antisipasi Kebijakan Perpajakan dalam Menghadapi ASEAN Economic Community. 2015.

RI'AYAH, Vol. 01, No. 01 Januari-Juni 2016 
pendidikan khususnya menjadi posisi yang sangat strategis sebagai upaya dalam mempersiapkan sumber daya manusia yang berkualitas dengan memiliki berbagai kompetensi serta orientasi yang lebih jauh dari seorang kariawan.

Lahirnya nilai-nilai wirausaha tidak lepas dari konstribusi pendidikan serta interaksi dengan lingkungan masyarakat. Sedangkan niat berwirausaha dapat muncul jika terjadi proses secara internal pada diri seseorang jika individu memiliki kesadaran personal dan sosial yang diwujudkan dengan pemahaman terhadap kemampuan diri, percaya diri, muncul motivasi diri dan memiliki daya juang dalam hidup. ${ }^{3}$ Sehingga peran dunia pendidikan termasuk perguruan tinggi untuk senantiasa membangun dan mengarahkan kemampuan serta minat para lulusan perguruan tinggi untuk bergerak dan mengembangkan kewirausahaan, sehingga sedikitnya lapangan pekerjaan saat ini tidak legi menjadi sebuah permasalahan yang krusial bagai setiap lulusan.

Mahasiswa sebagai agent of change yang memiliki peran penting dalam pembangunan pertumbuhan ekonomi, tentu harapan tersebut dapat terjadi ketika lembaga pendidikan melakukan transformasi selain transfer of knowladge tapi juga transfer values of entrepreneur dalam diri mahasiswa hingga menyadari bahwa berwirausaha bukanlah sebuah pekerjaan alternatif. Sehingga pada kesempatan ini satuan pendidikan perlu melakukan internalisasi nilai-nilai wirausaha dan membangun niat jiwa berwirausaha melalui pendidikan kewirausahaan maupun pengintegrasian kedalam berbagai mata pelajaran yang disajikan. Adapun artikel ini bersifat deskriptif analitik yaitu menggunakan teori-teori para ahli tentang pendidikan kewirausahaan dan niat kewirausahaan kemudian dilakukan analisa agar ditemukan titik efektifitas terhadap pendidikan kewirausahaan dalam membangun niat kewirausahaan.

\section{PEMBAHASAN}

\section{Pendidikan Kewirausahaan}

Pendidikan merupakan hal yang amat penting bagi kehidupan manusia, sebagai proses kehidupan dalam mengembangkan diri setiap individu untuk dapat hidup dan melangsungkan kehidupannya yang lebih baik. Dalam lingkungan pendidikan formal bahwa pendidikan merupakan upaya untuk mewujudkan suasana pembelajaran agar peserta didik secara aktif mengembangkan potensi dirinya serta mencapai sebuah tujuan pendidikan nasional sebagaimana tertuang dalam UU SISDIKNAS No 20 Th 2003 sebagai manusia yang cakap, kreatif, mandiri.

${ }^{3}$ Aisyah Khumairo, Bimbingan karir dalam menumbuhkan perilaku kewirausahaan santri di pondok pesantren entrepreneur ad-dhuha bantul yogyakarta. diss. UIN Sunan Kalijaga Yogyakarta, 2015.

RI'AYAH, Vol. 01, No. 01 Januari-Juni 2016 
Beberpa tahun yang lalu berbagai pendapat mengatakan bahwa kewirausahaan tidak dapat diajarkan melalui transfer pengetahuan layaknya di lembaga pendidikan. Akan tetapi pendapat tersebut tidak lagi bisa dipertahankan bahwa saat ini kegiatan kewirausahaan (Enterpreneurship) telah mampu menjadi mata pelajaran yang dapat diajarkan di lembaga pendidikan formal seperti halnya sekolah-sekolah dan perguruan tinggi, bahkan saat ini kegiatan tersebut memiliki pertumbuhan yang sangat pesat. Kegiatan transformasi pengetahuan kewirausahaan di berbagai negara telah memiliki perkembangan, bahkan di negara Indonesia sendiri pengetahuan kewirausahaan telah mulai diajarkan sejak sekolah-sekolah dasar, sekolah menengah, bahkan hampir disetiap jurusan perguruan tinggi.

Menurut Suparman bahwa: "Pendidikan kewirausahaan adalah pendidikan yang bertujuan untuk menempa bangsa Indonesia sesuai dengan kepribadian Indonesia yang berdasarkan Pancasila". Dalam arti yang lebih luas bahwa pendidikan kewirausahaan adalah pertolongan untuk membelajarkan manusia Indonesia sehingga mereka memiliki kekuatan pribadi yang dinamis dan kreatif sesuai dengan kepribadian bangsa Indonesia yang berdasarkan pancasila.

Hal ini menunjukan bahwa posisi pendidikan memiliki peran penting dalam mengimplementasikan pendidikan kewirausahaan, sebagai upaya pendidikan yang memiliki alternatif dalam menjawab permasalahan ekonomi, ketika para lulusan-lulusan sarjana masih berorientasi pada pencarian pekerjaan bukan bagaimana mampu menciptakan pekerjaan hingga mempekerjakan karyawan. Cara berpikir tersebut tentu harus diubah melalui berbagai pengalaman di lembaga pendidikan. Terlebih sudah banyak mahasiswa yang telah memasrahkan dirinya hanya untuk menjadi karyawan. Selain itu kegagalan dalam usaha telah menajdi momok bagi kebanyakan kalangan sehingga ia tidak ingin mencoba bahkan menanamkan niat untuk berwirausaha saja sudah menjadi suatu kejenuhan tersendiri.

Perguruan tinggi tentu berperan serta dalam mensejahterakan bangsa, dengan membangun ekonomi yang kini masih terpuruk. Berdasarkan kondisi objektif masyarakat, khususnya Perguruan Tinggi sebagai penghasil sumberdaya manusia berkualitas, ternyata masih belum mampu menghasilkan lulusan yang siap untuk berusaha secara mandiri memulai usahanya sendiri dan bukan hanya menunggu diberi pekerjaan. Hal ini di tandai dengan adanya seperti yang penulis kutip dari http://cibiko.blogspot.co.id bahwasanya : Angka penganguran lulusan PT yang cukup tinggi, kesulitan mencari kerja dengan masa tunggu yang cukup lama, over supplied lulusan secara kuantitas tetapi under supplied lulusan secara kualitas, perilaku jiwa kewirausaha lulusan masih rendah, relevansi lulusan dengan kebutuhan pasar kerja masih kurang, kecakapan hidup rendah, lemahnya penguasaan bahasa asing dan lemahnya peggunaan

RI'AYAH, Vol. 01, No. 01 Januari-Juni 2016 
teknologi informasi, kurang mampu bersaing dengan global, dan masih lemahnya jalinan kemitraan dengan dunia industri.

Sebelum melangkah lebih jauh dapat dipahami juga bahwa wirausaha merupakan orang yang terampil memanfaatkan peluang dalam mengembangkan usahanya dengan tujuan untuk meningkatkan kehidupannya. ${ }^{4}$ Menurut Z. Heflin Frinces dalam Yuyus Suryana mendefinisikan wirausaha adalah orang yang kreatif, dinamis, dan inovatif dan dia mau mengambil berbagai jenis resiko dan berani menghadapi semua tantangan yang tidak dapat diprediksi dan diramalkan sebelumnya, lewat kreativitasnya dan kekuatan kemauan untuk mencapai sukses. ${ }^{5}$ Norman M. Scarborough dan Thomas W. Zimmerer (1993:5), dalam Kemendiknas (2010), An entrepreneur is one who creates a newbusiness in the face if risk and uncertainty for the purpose of achieving profit andgrowth by identifying opportunities and asembling the necessary resources to capitalzeon those opportunities. Maksudnya wirausahawan adalah orang-orang yang memiliki kemampuan melihat dan menilai kesempatan-kesempatan bisnis, mengumpulkan sumber daya sumber daya yang dibutuhkan untuk mengambil tindakan yang tepat, mengambil keuntungan serta memiliki sifat, watak dan kemauan untuk mewujudkan gagasan inovatif kedalam dunia nyata secara kreatif dalam rangka meraih sukses / meningkatkan pendapatan. ${ }^{6}$ A.Lambing \& Charles R. Kuehl dalam buku Entrepreneurship yang dikutip Yuyus Suryana, kewirausahaan adalah suatu usaha yang kreatif yang membangun suatu value dari yang belum ada menjadi ada dan bisa dinikmati oleh orang banyak.7 Pengertian tersebut menunjukan bahwa wirausaha merupakan jiwa dari seseorang yang diekspresikan melalui sikap dan perilaku yang kreatif dan inovatif untuk melakukan suatu kegiatan demi meningkatkan kualitas kehidupanya. Dengan demikian, perlu ditegaskan bahwa tujuan pembelajaran kewirausahaan sebenarnya tidak hanya diarahkan untuk menghasilkan pembisnis atau business entrepreneur, tetapi mencakup seluruh profesi yang didasari oleh jiwa wirausaha atau entrepreneur.

Sehingga bakal calon pengusaha atau pembisnis perlu memiliki kekuatan dalam menghadapi berbagai tantangan dan resiko dikemudian

\footnotetext{
${ }^{4}$ Kementerian Pendidikan Nasional. Pengembangan Pendidikan Kewirausahaan. Bahan PelatihanPenguatan Metodologi Pembelajaran Berdasarkan Nilai-Nilai Budaya untuk Membentuk Daya Saingdan Karakter Bangsa. Jakarta: Badan Penelitian dan Pengembangan Pusat Kurikulum. 2010

5 Yuyus Suryana dan Kartib Bayu, Kewirausahaan: Pendekatan Karakteristik Wirausahawan Sukses (Jakarta: Kencana, 2010), hlm. 30

${ }^{6}$ Kementerian Pendidikan Nasional. Pengembangan Pendidikan Budaya dan Karakter Bangsa. Bahan Pelatihan Penguatan Metodologi Pembelajaran Berdasarkan Nilai-Nilai Budaya untuk MembentukDaya Saing dan Karakter Bangsa. Jakarta: Badan Penelitian dan Pengembangan Pusat Kurikulum. 2010

${ }^{7}$ Yuyus Suryana dan Kartib Bayu, Kewirausahaan:...... hlm. 33
}

RI'AYAH, Vol. 01, No. 01 Januari-Juni 2016 
hari. Adapun kekuatan yang perlu dipahami adalah " $4 \mathrm{H}^{\text {" }} .8 \mathrm{H}$ pertamahead atau kepala yang diartikan sebagai pemikiran, dan dalam pembelajaran diisi oleh pengetahuan tentang nilai nilai, semangat, jiwa, sikap dan perilaku, agar peserta didik memiliki pemikiran kewirausahaan. $\mathrm{H}$ kedua, heart atau hati yang diartikan sebagai perasaan, diisi oleh penanaman empatisme sosial-ekonomi, agar peserta didik dapat merasakan suka-duka berwirausaha dan memperoleh pengalaman empiris dari para wirausaha terdahulu. Selanjutnya $\mathrm{H}$ ketiga, hand atau tangan yang diartikan sebagai keterampilan yang harus dimiliki oleh peserta didik untuk berwirausaha. Oleh karena itu dalam konteks ini pembelajaran kewirausahaan membekali peserta didik dengan teknik produksi agar mereka kelak dapat berproduksi atau menghasilkan produk baik berupa barang, jasa maupun ide. dan $\mathrm{H}$ keempat, health atau kesehatan yang diartikan sebagai kesehatan fisik, mental dan sosial. Sehubungan dengan hal ini, peserta didik hendaknya dibekali oleh teknik-teknik antisipasi terhadap berbagai hal yang mungkin timbul dalam berwirausaha baik berupa persoalan, masalah maupun risiko lainnya sebagi wirausaha. Pembelajaran untuk hal ini dapat diberikan melalui AMT (Achievement Motivation Training) atau Outbond Training.

Dalam hal ini tentu pendidikan kewirausahaan menjadi vital dalam kehidupan, sebagai usaha yang mampu mengubah pola pikir yang selalu berorientasi ketika lulus dari pendidikan mencari pekerjaan berputar balik bagaimana bisa menciptakan pekerjaan. Dengan demikian pendidikan kewirausahaan dapat diajarakan melalui proses pembelajaran dengan melakukan penanaman nilai-nilai kewirausahaan hingga setiap individu mampu memahami hingga pada zona feeling yang akan menggungah hatinya akan pentingnya kewirausahaan.

Disamping itu pendidikan kewirausahaan dapat dilakukan melalui satu mata pelajaran kewirausahaan atau juga dapat diintegrasikan dalam mata pelajaran yang lain. ${ }^{9}$ Materi pembelajaran yang berkaitan dengan norma atau nilai-nilai pada setiap mata pelajaran perlu dikembangkan, dieksplisitkan, dikaitkan dengan konteks kehidupan sehari-hari. Dengan demikian, pembelajaran yang berwawasan pendidikan kewirausahaan tidak hanya pada tataran kognitif, tetapi menyentuh pada internalisasi, dan pengamalan nyata dalam kehidupan peserta didik sehari-hari di masyarakat.

Adapun perlunya pendidikan kewirausahaan di Indonesia menurut R. Djatmiko Danuhadimedjo (1998) adalah:

1. Untuk mengembangkan, memupuk dan membina bibit atau bakat pengusaha sehingga bibit tersebut lebih berbobot dan selalu mengikuti perkembangan ilmu pengetahuan yang mutakhir.

\footnotetext{
${ }^{8}$ Eman Suherman, Business Entrepreneur (Bandung: Alfabeta 2010), hlm 134

9 Endang Mulyani, "Model Pendidikan Kewirausahaan di Pendidikan Dasar dan Menengah." Jurnal Ekonomi \& Pendidikan 8.1. 2012
}

RI'AYAH, Vol. 01, No. 01 Januari-Juni 2016 
2. Untuk memberikan kesempatan kepada setiap manusia supaya sedapat mungkin dan menumbuhkan kepribadian wirausaha.

3. Pendidikan kewirausahaan menjadi manusia berwatak dan unggul, memberikan kemampuan untuk membersihkan sikap mental negatif meningkatkan daya saing dan daya juang.

4. Dengan demikian apabila kepribadian wirausaha kita miliki, maka negara kita yang sedang berkembang ini akan dapat menyusul ketinggalan atau menyamai negara yang sudah maju.

5. Untuk menumbuhkan cara berpikir yang rasional dan produktif dalam memanfaatkan waktu dan faktor-faktor modal yang dimiliki oleh wirausaha tradisional pribumi.

Sehingga dalam hal ini pendidikan kewirausahaan bertujuan untuk membentuk manusia secara holistik, sebagai insan yang memiliki nilai-nilai karakter, pemahaman dan ketrampilan sebagai wirausaha. Sebagaimana disinggung diawal pada dasarnya pendidikan kewirausahaan dapat diimplementasikan selain dengan disiplin ilmu sendiri juga dapat dilakukan secara terpadu dengan berbagai kegiatan-kegiatan pendidikan di sekolah ataupun perguruan tinggi. Adapun kegiatan pendidikan kewirausahaan yang dipadukan melalui seluruh mata pelajaran adalah dengan melakukan internalisasi nilai-nilai kewirausahaan kedalam berbagai mata pelajaran yang disajikan oleh setiap pendidik melalui proses pembelajaran dalam hal ini metode, strategi, pendekatan, bahan dan lingkungan pemebelajaran itu sendiri baik di dalam kelas maupun diluar kelas. Sehingga melalui aktivitas ini diharapkan peserta didik atau mahasiswa memiliki kesadaran terhadap betapa pentingnya memahami nilai-nilai kewirausahaan hingga memiliki kepedulian terhadap dirinya dalam membangun niat entrepreneur. Adapaun nilai-nilai kewirausahaan dalam hal ini menurut Buchari Alma (2011) antara lain:

1. Percaya Diri, indikatornya: penuh keyakinan, optimis, berkomitmen, disiplin dan tanggung jawab.

2. Inisiatif, indikatornya: energik, cekatan dalam bertindak, dan aktif.

3. Memiliki Motif Berprestasi, indikatornya: orientasi pada hasil dan wawasan ke depan.

4. Memiliki Jiwa Pemimpin, indikatornya: dapat dipercaya, tangguh dalam bertindak.

5. Berani, indikatornya: harus bertindak cepat dalam mengambil resiko dengan penuh perhitungan.

6. Orisinalitas, indikatornya diantaranya: punya referensi yang cukup, tidak menyontek/plagiat.

Disisi lain Alma menyatakan bahwa nilai-nilai dasar yang penting untuk dipegang dan dijadikan dasar bagi seorang entrepreneur antara lain: kreativitas, inovatif, berani menghadapi risiko, memiliki etika bisnis dan

RI'AYAH, Vol. 01, No. 01 Januari-Juni 2016 
norma, serta semangat dan bertanggung jawab. Modal utama entrepreneur adalah kreativitas, keuletan dan semangat bekerja. Semangat pantang menyerah ini memandang kegagalan hanya keberhasilan yang tertunda dan mereka tahan banting. ${ }^{10}$ Entrepreneur yang kreatif memiliki perhitungan cermat, mempertimbangkan segala fakta, informasi dan data. Seorang entrepreneur mampu memadukan apa yang ada di dalam hati, pikiran dan kalkulasi bisnis.

Kreativitas adalah kemampuan untuk membuat kombinasi-kombinasi baru atau melihat hubungan-hubungan baru antara unsur, data dan variabel yang sudah ada. Kreativitas merupakan kemampuan seseorang untuk melahirkan sesuatu yang baru, baik berupa gagasan atau karya nyata, yang relatif berbeda dengan apa yang telah ada sebelumnya. ${ }^{11}$ Kreativitas dan inovasi tentu memiliki hubungan yang erat. Dimana kreativitas memiliki makna kemampuan untuk memikirkan sesuatu yang baru dan berbeda, sedangkan inovasi merupakan kemampuan untuk melakukan, mengaplikasikan sesuatu yang berbeda. Dengan demikian, yang paling penting dalam entrepreneurship adalah kemampuan pengusaha untuk lebih kreatif dan memanfaatkan inovasi dalam kegiatan bisnisnya sehari-hari. Seorang pengusaha akan berhasil apabila ia selalu kreatif dan menggunakan kreativitasnya tersebut. Diperjelas oleh Gwee (2007) bahwa, untuk menghadapi persaingan yang semakin kompleks dalam persaingan ekonomi global, maka kreativitas menjadi sangat penting untuk menciptakan keunggulan kompetitif dan kelangsungan bisnis. Nilai-nilai dasar yang penting dalam entrepreneur antara lain: kreativitas, inovatif, berani menghadapi risiko, memiliki etika bisnis dan norma yang baik, serta bertanggung jawab dan memiliki disiplin diri.

\section{Niat Berwirausaha (Entrepreneurial Intentions)}

Entrepreneurial intention atau niat kewirausahaan dapat diartikan sebagai langkah awal dari suatu proses pendirian sebuah usaha yang umumnya bersifat jangka panjang. ${ }^{12}$ Krueger mengatakan niat kewirausahaan mencerminkan komitmen seseorang untuk memulai usaha baru dan merupakan isu sentral yang perlu diperhatikan dalam memahami proses kewirausahaan pendirian usaha baru. ${ }^{13}$

Hal. 24

${ }^{10}$ Alma, B. Keentrepreneuran untuk mahasiswa dan umum. Bandung: Alfabeta. 2008.

${ }^{11}$ Nur Kholifah \& Muhammad Nurtanto, Pengembangan Pendidikan Kewirausahaan dalam Menanamkan Nilai-nilai Entrepreneurship untuk Menghadapi Masyarakat Ekonomi ASEAN (MEA), Prosiding Seminar Nasional Inovasi Pendidikan.

${ }^{12}$ Lee, S.H. \& Wong, P.K. An Exploratory Study of Technopreneurial Intentions: A Career Anchor Perspective. Journal of Business Venturing, 2004. 19(1): 7-28.

${ }^{13}$ Krueger, N. The Impact of Prior Entrepre-neurial Exposure on Perceptions of New Venture Feasibility and Desirability. Entrepre-neurial Theory Practice, 1993. 18(1): 5-21.

RI'AYAH, Vol. 01, No. 01 Januari-Juni 2016 
Pada dasarnya pembentukan jiwa kewirausahaan dipengaruhi oleh faktor internal dan eksternal. ${ }^{14}$ Faktor internal yang berasal dari dalam diri wirausahawan dapat berupa sifat-sifat personal, sikap, kemauan dan kemampuan individu yang dapat memberi kekuatan individu untuk berwirausaha. Sedangkan faktor eksternal berasal dari luar diri pelaku entrepreneur yang dapat berupa unsur dari lingkungan sekitar seperti lingkungan keluarga, lingkungan dunia usaha, lingkungan fisik, lingkungan sosial ekonomi dan lain-lain.15

Dalam membangun niat kewirausahaan terdapat beberapa faktor yang perlu diperhatikan sebagai faktor yang mempengaruhi lahirnya niat dalam berwirausaha, Johnson dalam Lieli menyatakan bahwa niat kewirausahaan seseorang dipengaruhi oleh sejumlah faktor yakni faktor internal, faktor eksternal dan faktor kontekstual. ${ }^{16}$ Faktor internal yaitu kecakapan pribadi yang menyangkut soal bagaimana kita mengelola diri sendiri melalui kesadaran, pengetahuan dan motivasi. faktor eksternal berasal dari luar diri pelaku entrepreneur yang dapat berupa unsur dari lingkungan sekitar seperti lingkungan keluarga, lingkungan dunia usaha, lingkungan fisik, lingkungan sosial ekonomi dan lain-lain. Faktor eksternal, yaitu kecakapan sosial yang menyangkut soal bagaimana kita menangani suatu hubungan. kecakapan sosial seseorang terdiri atas dua unsur terpenting seperti empati dan keterampilan sosial. Faktor kontekstual adalah peranan pendidikan kewirausahaan dan pengalaman kewirausahaan. Secara teori diyakini bahwa pembekalan pendidikan dan pengalaman kewirausahaan pada seseorang sejak usia dini dapat meningkatkan potensi seseorang untuk menjadi wirausahawan. Selain pendidikan dan pengalaman kewirausahaan, dukungan pihak akademik (academic support), social support dan dukungan lingkungan usaha juga diduga merupakan faktor kontekstual yang berpengaruh terhadap niat kewirausahaan.

Harti Lieli and Hani Sirine dalam penelitianya Faktor-Faktor yang Mempengaruhi Niat Kewirausahaan Mahasiswa menyatakan bahwasanya ada tiga faktor yang mempengaruhi niat kewirausahaan mahasiswa diantaranya: ${ }^{17}$

1. Faktor-faktor sosio demografi dalam hal ini pekerjaan orangtua sebagai wirausahawan dan pengalaman berwirausaha mahasiswa

${ }^{14}$ Priyanto S.H. Di dalam Jiwa ada Jiwa: The Backbone and the Social Construction of Entrepreneurships. Pidato Pengukuhan Guru Besar Universitas Kristen Satya Wacana, 2008.

15 Lieli Suharti, and Hani Sirine. "Faktor-Faktor yang Berpengaruh Terhadap Niat Kewirausahaan (Entrepreneurial Intention)." Jurnal Manajemen dan Kewirausahaan (Journal of Management and Entrepreneurship), 2012. 13.2 : 124-134.

16 Ibid.

17 Ibid.

RI'AYAH, Vol. 01, No. 01 Januari-Juni 2016 
2. Faktor-faktor sikap (attitudes) yaitu autonomy/ authority, economic challenge, self realization, security $\mathcal{E}$ workload, terbukti berpengaruh secara signifikan dan positif terhadap niat kewirausahaan mahasiswa.

3. Faktor-faktor kontekstual yaitu, academic support dan social support, terbukti berpengaruh secara signifikan dan positif terhadap niat kewirausahaan mahasiswa.

Selain lembaga pendidikan yang memiliki pengaruh dalam menanamkan niat wirausaha kepada mahasiswa maka dorongan dari unsurunsur lingkungan sosial seperti motivasi dari teman dekat, orang-orang yang dianggap penting serta keluarga memiliki berpengaruh secara positif terhadap niat kewirausahaan. Oleh karena itu untuk mendorong timbulnya niat mahasiswa untuk berwirausaha setelah lulus sarjana perlu mendapat dukungan dari pihak keluarga dan teman-teman terdekat.

Niat merupakan bagian pertama sebelum manusia melakukan sesuatu pekerjaan. Sehingga niat dapat dikatakan sebagai kekuatan yang ada pada diri setiap individu, layaknya sebuah gravitasi bumi yang akan selalu menarik kuat benda yang ada di atasnya. Karena dengan niat tersebut akan menyadari bahwa adanya kekuatan yang sangat besar yang mendorong dalam menggapai cita-cita dan impian.

Sehingga niat memiliki peran penting dalam setiap pekerjaan yang akan dilaksanakan bahkan diyakini bahwa suatu niat yang berkaitan dengan perilaku terbukti dapat menjadi cerminan dari perilaku yang sesungguhnya. Dalam teori planned behavior dalam Tjahjono \& Ardi diyakini bahwa faktorfaktor seperti sikap, norma subyektif akan membentuk niat seseorang dan selanjutnya secara langsung akan berpengaruh pada perilaku. ${ }^{18}$ Oleh karena itu pemahaman tentang niat seseorang untuk berwirausaha (entrepreneurial intention) dapat mencerminkan kecenderungan orang untuk mendirikan usaha secara riil. ${ }^{19}$

\section{Membangun Entrepreneurial Intentions Mahasiswa melalui Pendidikan Kewirausahaan}

Pendidikan kewirausahaan memiliki peran penting dalam membangun niat wirausaha, sebagai kegiatan trensfer of values wirausaha agar ketita setiap individu membangun usaha tidak lagi meraba-raba peluang bisnis dan akan lebih peke terhadap berbagai kesempatan yang dihadapanya. Dengan adanya pendidikan tersebut maka mereka juga akan mempertimbangkan semua yang akan mereka lakukan dengan matang. Pendidikan akan membentuk para wirausahawan atau pebisnis yang handal

${ }^{18}$ Tjahjono, H.K. \& Ardi, H. Kajian Niat Mahasiswa Manajemen Universitas Muhammadiyah Yogyakarta untuk Menjadi Wira-usaha. Utilitas Jurnal Manajemen dan Bisnis, 2008. 16(1): 46-63

19 Jenkins, M. \& Johnson, G. Entrepreneurial Intentions and Outcomes: A Comparative Causal Mapping Study. Journal Management Studies, 1997. 34, 895-920

RI'AYAH, Vol. 01, No. 01 Januari-Juni 2016 
dan tangguh. Siap menghadapi tantangan yang akan mereka hadapi. Besar kecilnya resiko akan mereka pertimbangkan matang-matang, melakukan segala hal dengan petunjuk yang mereka ketahui tanpa adanya kebimbangan yang tidak pasti.

Sehingga dalam hal ini pengaruh dunia pendidikan terhadap perkembangan jiwa seseorang termasuk jiwa wirausaha sebenarnya berbeda dengan pengaruh eksternal yang lain. Pada umumnya pengaruh lingkungan sosial masyarakat bersifat lebih cendrung pasif, dalam arti bahwa lingkungan tidak memberikan suatu paksaan terhadap individu, lingkungan hanya memberikan kesempatan-kesempatan atau peluang sebagai kesempatan untuk mengembangkan diri. Menurut Dwi Wahyo ${ }^{20}$ dalam penelitianya menyatakan bahwa faktor utama yang perlu menjadi perhatian adalah sikap berwirausaha dan efikasi diri dengan memberikan bekal pengembangan sikap dalam menanggapi peluang yang ada serta mentoleransi risiko dalam usaha. Efikasi diri dapat ditingkatkan dengan memberikan bekal pengetahuan dan keterampilan berwirausaha. Selain itu hasil penelitian ini juga dapat memberikan kontribusi bagi dunia pendidikan khususnya pendidikan kewirausahaan agar memperhatikan sikap berwirausaha dan efikasi diri sebagai faktor internal atau personal. Pola pendidikan kewirausahaan yang diberikan kepada mahasiswa perlu memiliki upaya internalisasi nilai-nilai percaya diri seperti halnya keyakinan, ketidak tergantungan, individualitas, dan optimisme sebagai upaya membangun jiwa inovatif dan kreatif dalam menanggapi peluang, menciptakan peluang serta keterampilan dan pengetahuan berwirausaha seperti mendirikan usaha dan mengelola usaha.

Bagaimana individu mengambil kesempatan atau peluang tersebut tergantung pada yang bersangkutan. Tidak demikian halnya dengan pendidikan, terutama yang langsung berhubungan dengan wirausaha. Pendidikan dijalankan dengan penuh kesadaran, mempunyai tujuan, target, dan sasaran tertentu serta diberikan secara sistematis untuk mengembangkan potensipotensi wirausaha yang ada. ${ }^{21}$

Wasty Soemanto mengatakan bahwa22: Satu-satunya perjuangan atau cara untuk mewujudkan manusia yang mempunyai moral, sikap, dan keterampilan wirausaha adalah dengan pendidikan. Dengan pendidikan, wawasan individu menjadi lebih percaya diri, bisa memilih dan mengambil keputusan yang tepat, meningkatkan kreativitas dan inovasi, membina moral, karakter, intelektual, serta peningkatan kualitas sumber daya manusia

${ }^{20}$ Ranto, Dwi Wahyu Pril, and Akademi Manajemen Administrasi YPK. "Membangun Perilaku Entrepreneur Pada Mahasiswa Melalui Entrepreneurship Education." JBMA Vol. III, No. 1, Maret 2016

${ }^{21}$ Wibowo, Muladi. "Pembelajaran kewirausahaan dan minat wirausaha lulusan SMK." Eksplanasi 6.2 (2012).

${ }^{22}$ Wasty Soemanto, Pendidikan Wiraswasta, Jakarta : Bumi Aksara. 2002. Hal. 78

RI'AYAH, Vol. 01, No. 01 Januari-Juni 2016 
yang lain sehingga akhirnya mampu berdiri sendiri. Pendidikan juga berfungsi untuk membentuk kepribadian seseorang menjadi lebih kuat dan tahan hantaman. Kepribadian yang kuat merupakan salah satu modal pokok bagi seorang wirausahawan. Hanya perlu diingat bahwa untuk membentuk elemen kualitas sumber daya manusia yang diinginkan tersebut diperlukan waktu yang panjang, bahkan konsepsi pendidikan seumur hidup (Life-long education) menuntut partisipasi dari berbagai pihak, bukan hanya sekolah. Sehingga dengan berbagai usaha ini mampu menciptakan Entrepreneur Intentions terhadap setiap mahasiswa.

\section{PENUTUP}

Dalam implementasinya pendidikan kewirausahaan dapat dilakukan melalui satu mata pelajaran atau pengintegrasian dalam mata pelajaran yang lain. Sehingga terselenggaranya efektifitas ekonomi di suatu negara tidak lepas dari upaya dunia pendidikan, sebapai posisi yang setrategis dalam mempersiapkan sumber daya manusia yang berkualitas dengan memiliki kekuatan dalam menghadapi tantangan dan resiko. Kekuatan tersebut seperti halnya head atau sebagai pemikiran, heart atau perasaan, hand atau keterampilan, health atau kesehatan selain itu individu memiliki nilai-nilai kewirausahaan seperti halnya percaya diri, Inisiatif, memiliki jiwa pemimpin, berani, orisinalitas, kreativitas, inovatif, berani menghadapi risiko, memiliki etika bisnis dan norma yang baik, serta bertanggung jawab dan memiliki disiplin diri.

Disi lain niat kewirausahaan (Entrepreneurial intention) menjadi langkah awal dari suatu proses pendirian sebuah usaha, sehingga menjadi suatu pertimbangan berbagai faktor yang mampu mempengaruhi lahirnya sebuah niat yang kuat seperti faktor eksternal (keluarga, dunia usaha, fisik, sosial), faktor internal (sikap, kemauan dan kemampuan), dan faktor kontekstual (pendidikan kewirausahaan dan pengalaman). Alhasil dengan lahirnya sebuah niat yang tulus dalam setiap pekerjaan yang akan dilaksanakan bahkan diyakini bahwa suatu niat yang berkaitan dengan perilaku terbukti dapat menjadi cerminan dari perilaku yang sesungguhnya. Pada akhirnya lembaga pendidikan tetap menjadi posisi yang sangat penting dalam internalisasi nilai-nilai kewirausahaan kepada mahasiswa, sehingga mampu menjadi bekal awal bagi setiap individu dalam menghadapai masyarakat ekonomi asean yang telah hadir di hadapan mata.

\section{DAFTAR PUSTAKA}

Alma, B. Keentrepreneuran untuk mahasiswa dan umum. Bandung: Alfabeta. 2008.

Eman Suherman, Business Entrepreneur, Bandung: Alfabeta 2010

RI'AYAH, Vol. 01, No. 01 Januari-Juni 2016 
Harti, Lieli, and Hani Sirine. "Faktor-Faktor yang Berpengaruh Terhadap Niat Kewirausahaan (Entrepreneurial Intention)." Jurnal Manajemen dan Kewirausahaan (Journal of Management and Entrepreneurship) 2012

Imaroh, Tukhas Shilul. "Pendidikan Entrepreneurship Sebagai Strategi Peningkatan Daya Saing Bangsa dalam Menghadapi AEC." Prosiding Seminar Nasional "Antisipasi Kebijakan Perpajakan dalam Menghadapi ASEAN Economic Community. 2015

Jenkins, M. \& Johnson, G. Entrepreneurial Intentions and Outcomes: A Comparative Causal Mapping Study. Journal Management Studies, . 1997

Kementerian Pendidikan Nasional. Pengembangan Pendidikan Budaya dan Karakter Bangsa. Bahan Pelatihan Penguatan Metodologi Pembelajaran Berdasarkan Nilai-Nilai Budaya untuk MembentukDaya Saing dan Karakter Bangsa. Jakarta: Badan Penelitian dan Pengembangan Pusat Kurikulum. 2010

.Pengembangan Pendidikan Kewirausahaan. Bahan PelatihanPenguatan Metodologi Pembelajaran Berdasarkan Nilai-Nilai Budaya untuk Membentuk Daya Saingdan Karakter Bangsa. Jakarta: Badan Penelitian dan Pengembangan Pusat Kurikulum. 2010

Kholifah, Nur, and Muhammad Nurtanto. "Pengembangan Pendidikan Kewirausahaan Dalam Menanamkan Nilai-Nilai Entrepreneurship Untuk Menghadapi Masyarakat Ekonomi ASEAN (MEA)." Prosiding Seminar Nasional Inovasi Pendidikan. 2016

Khumairo, Aisyah, and s. sos. Bimbingan karir dalam menumbuhkan perilaku kewirausahaan santri di pondok pesantren entrepreneur ad-dhuha bantul yogyakarta. diss. UIN Sunan Kalijaga Yogyakarta, 2015

Krueger, N. The Impact of Prior Entrepre-neurial Exposure on Perceptions of New Venture Feasibility and Desirability. Entrepre-neurial Theory Practice, 1993

Lee, S.H. \& Wong, P.K. An Exploratory Study of Technopreneurial Intentions: A Career Anchor Perspective. Journal of Business Venturing,2004

Mulyani, Endang. "Model Pendidikan Kewirausahaan di Pendidikan Dasar dan Menengah." Jurnal Ekonomi \& Pendidikan, 2012

Priyanto S.H. Di dalam Jiwa ada Jiwa: The Backbone and the Social Construction of Entrepreneurships. Pidato Pengukuhan Guru Besar Universitas Kristen Satya Wacana. 2008

Soesastro, Hadi. Kebijakan Persaingan, Daya Saing, Liberalisasi, Globalisasi, Regionalisasi dan Semua Itu, Economics Working Paper Series CSIS, 2004. 
Suharti, Lieli, and Hani Sirine. "Faktor-Faktor yang Berpengaruh Terhadap Niat Kewirausahaan (Entrepreneurial Intention)." Jurnal Manajemen dan Kewirausahaan (Journal of Management and Entrepreneurship) 2012

Tjahjono, H.K. \& Ardi, H. Kajian Niat Mahasiswa Manajemen Universitas Muham-madiyah Yogyakarta untuk Menjadi Wira-usaha. Utilitas Jurnal Manajemen dan Bisnis, 2008

Yuyus Suryana dan Kartib Bayu, Kewirausahaan: Pendekatan Karakteristik Wirausahawan Sukses, Jakarta: Kencana, 2010 